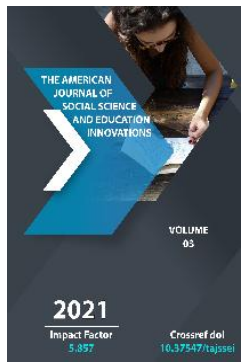

\title{
The Factors That Form Students' Creative Relationships In The Educational Process
}

Mom'inova Oftobxon Karimovna

Teacher, Department Of Teaching Languages, Fergana Polytechnic Institute, Fergana, Uzbekistan

Journal Website:

http://theamericanjour

nals.com/index.php/taj

ssei

Copyright: Original content from this work may be used under the terms of the creative commons attributes 4.0 licence.

\section{ABSTRACT}

To effectively organize the educational process as a skilled educator, it is well aware of the professional qualities required for teachers, able to organize the learning process effectively on the basis of creative, modern pedagogical technologies and we can tell the teacher to bring. This article explores the factors forming the creative attitude to the educational process.

\section{KEYWORDS}

Critical thinking , Question and answer , Ability , Development, Skills , Teaching Technology

\section{INTRODUCTION}

In the traditional system of education, the teacher is the central subject, while in the modern system of education, the student is the main subject. That is, in the centre of pedagogical activity is not the teacher, as in traditional education, but the student's cognitive activity, the development of his intellectual abilities. The formation of the 
intellectual potential of the future teacher involves not only the study and mastery of the basics of science but also the acquisition of purposeful methods of mental activity. Mental activity determines not only the acquisition of the basics of knowledge but also the experience of comparing, analysing, synthesizing, abstracting, generalizing and applying the acquired knowledge in different situations. In this way, an effective method of activity is generalized, and a general method of performing different types of activities using different methods is formed. The ability to think independently is important in preparing a future teacher for creative activity. Therefore, in the education system, it is necessary to teach future teachers to think, to observe the acquired knowledge.

"The education of thought," said the great enlightener Abdulla Avloni, "is a sacred honour, a zeal, which has been studied for a long time, which has been entrusted to the attention of teachers, and which has been entrusted to their consciences."

\section{MATERIALS AND METHODS}

Thinking ability refers, firstly, to the acquisition of information, information, their comparison and generalization, and secondly, the experience of applying the acquired knowledge in the organization of activities in different situations. To develop this skill, it is important to train future teachers to solve various problems independently, to teach them to solve simple and then complex exercises, depending on the system of actions and content. In this case, it is advisable to teach critical thinking, paying special attention to the process of planning tasks (analysis, selection of methods and order of execution).
Critical thinking is a natural way of combining ideas and information, and in the process, it is also important to evaluate the results of the work that is, self-monitoring. The educational experience of the Republic and developed countries shows that critical thinking is a way to discuss different ideas and opinions, to respect the personal views of future teachers, to create conditions for them to think and to develop their intellectual abilities allows you to determine the lim conditions. Question and answer organization is also an important tool for improving and developing thinking processes. It is important to note that an important feature that distinguishes effective, (productive) thinking from reproductive thinking is the independent discovery of new knowledge. The highest levels of effective thinking are creative thinking, thinking, innovating, inventing, and so on. The use of models proposed by B.Blum, V.P.Bespalko, M.A.Choshanov, G.I.Shukina, V.V.Davidov, E.Gaziyev, B.Kadirov and others in the development of intellectual abilities of young people, including future teachers, has achieved positive results allows you to enter [1-3]. Today's demand does not allow for an endless expansion of the content and scope of education, but also requires the preparation of future teachers to solve existing problems unconventionally. The system of theoretical concepts mastered or formed in the mind of the future teacher becomes the basis of educational activity. Improving the student's academic performance, that is, the formation of his intellectual, thinking skills, should be the main result of modern education.

It should also be noted that the basis of mental development is the stratification of cognitive processes. After all, stratification is 
an important process in the transition from direct emotional cognition to abstract solutions. Modern learners have the following tasks:

- Ability to adapt to rapid changes, vital activities, as well as the ability to apply the acquired knowledge in solving existing problems;

- To be able to think independently and critically, to understand the essence of real and emerging problems, to find ways to solve them using modern pedagogical technologies;

- To find effective ways to apply the acquired knowledge in practice, to come up with new ideas and think creatively;

- Be able to effectively use and apply information technologies promptly.

The depth and robustness of the knowledge of learners, including prospective teachers, is determined not only by their sum but also by their structure. For the intellectual development of future teachers, it is important to take into account the characteristics of mental activity and choose methods in the processing of information [46]. The basis of mental activity is knowledge, memory, new ideas and their expression and evaluation. Types of cognitive processes and thinking activities can be recognized as important factors in teaching knowledge to future teachers.

In the practice of educational institutions of the Republic, the individualization of education is important in the intellectual development and upbringing of future teachers. Individualization can take place in all forms of learning: collective, group and individual. All this plays an important role in preparing a future teacher for creative activity. Creating creativity in a future teacher requires a new approach, a new approach. The formation of creativity remains a spiritual factor in the development of society in the XXI century.

\section{RESULTS AND DISCUSSION}

Traditional education did not have much potential for developing the creative abilities of future teachers. An important condition for the ability to be creative is to intensify this process, to achieve the creative nature of the cognitive activities of future teachers. This is not to convey ready knowledge to the student, but:

- Orientation of teachers to cooperation with future teachers;

- $\quad$ Prepare future teachers to activate their activities by restricting them from following orders.

Therefore, active learning is an important condition for the development of creative abilities in future teachers. Learning activity is a state of the future teacher's activity in which the future teacher's desire to learn, focus on mental cognition and demonstrate willpower are manifested in the following situations of professional activity:

- Intensive development of cognition, attention, memory, thinking in the process of learning in the creative activity of the student; 
- knowledge and observance of moral and ethical norms (good and evil, compassion and envy, courage and cowardice);

- Understand their personal characteristics and the nature of life's problems;

- Be able to demonstrate personal capabilities and abilities;

- Be able to work on themselves, understand their personal shortcomings and prevent them;

- Self-esteem and self-esteem;

- Increase cognitive activity, enrich imagination, expand knowledge, experience and interests.

The conditions for the development of creative abilities of future teachers are:

- To arouse the emotions of future teachers in each lesson, to achieve satisfaction with their work;

- To get acquainted with the level of potential and abilities of future teachers;

- Development of individual programs of work with talented future teachers;

- Be able to communicate with different social groups;

- Be able to independently work on the development of their morals, scientific potential, cultural level;

- Be creative in their approach to change, taking a creative approach to the laws of the interrelation of things and events around them;
- Encouragement to learn, adherence to ethical requirements.

Independent research, solving creative tasks, summarizing the results are directly related to emotional experiences, which are naturally reflected in the student's speech. It also requires the development of language culture in the preparation of future teachers for pedagogical and creative activities. Knowledge of language satisfies human needs as a means of communication, communication, communication, cognition, activity planning and communication, emotional-aesthetic and spiritual-moral influence, education [6-9]. According to the results of psychological and pedagogical research, attention is paid to the unity of thought and emotion about human logic. In other words, emotions make a person human. This shows the importance of comparing different points of view. After all, based on the comparison, the logical and cognitive perceptions of the future teacher are expressed through language.

The importance of comparison in the process of thinking and knowing has been emphasized by critical scholars such as Muhammad Musa al-Khwarizmi, Abu Nasr al-Farabi, Abu Rayhan al-Beruni, and Abu Ali ibn Sina, who believe that understanding information is the basis of thinking. The essence of any event that takes place in existence is understood on the basis of comparison. Therefore, it is advisable to train future teachers to compare in the educational process. Comparisons are general and specific. Generality is reflected in the scope of all disciplines (analysis, synthesis, comparison, etc.), and specificity is reflected in the process of mastering educational materials on a particular subject. The available 
literature confirms that the analysis consists of the following four steps:

- Separation of initial characters;

- Identify common and important features;

- Separation of bases for comparison;

- Comparison based on the given basic signs.

The development of the intellectual abilities of the future teacher is a requirement of the time, and an important basis for its development is a teacher with a high level of intellectual ability:

- Is able to adapt to fast-changing tasks;

- Able to actively use existing knowledge, skills and abilities in solving life problems;

- Can critically react to events, analyse existing problems, find ways out of the situation;

- Can explain new ideas, creative ideas to others;

\section{- Can absorb information literately}

Today, the worldview of the future teacher, his role in society, the determination of the relationship between teacher and future teacher, the relationship between the individual and the state, the individual and society, his duties and responsibilities, creative ability and it is important to build the intellectual potential. The "Concept of pedagogical science" compiled by the group of authors (R.H. Jorayev, R. Safarova, H. I. Ibragimov, U.K. Musayev) emphasizes the expediency of reflecting the following in the content of person-centred education: - The knowledge that must be acquired in the educational process corresponds to the needs and interests of the state and society, the individual, science, industry and the social sphere.

It is usually advisable for prospective teachers to have a creative approach to the pedagogical profession, identifying their individual capabilities for the requirements of their chosen profession and activity. For example, in choosing a teaching profession, not only a love of the profession, the desire to communicate with children, but also the fact that the physical, psychological and social requirements of the profession to the individual are within its capabilities to acquire professional knowledge, skills and abilities. Therefore, special attention should be paid to the development of the professional potential of future teachers. The initial potential preparation of future teachers for professional activity is the basis of their current practical training. Therefore, in the process of formation of professional training in educational institutions, it is necessary to form in students the professional knowledge, skills and abilities sufficient for the implementation of professional activities. It should be noted that the product of educational activity in higher education institutions is the process of acquiring professional knowledge. However, there are times when a well-prepared professional may not be ready for the job at the right time. In this case, pedagogical activity cannot be successful or ineffective. The professional training of a specialist includes not only the required level of professional knowledge but also psychological training, self-management and orientation to the desired activity, 
management of the educational process, professional, spiritual and physical capabilities. formation of professional skills and competencies related to the ability to direct the solution of the problem in the right conditions, adaptation to the process. Because these skills and competencies are considered to be necessary phenomena in the process of creative approach of future teachers to the profession. Professional skills and competencies are an automated way of transforming a person's acquired professional knowledge into comprehensible actions that arise in the course of practical activities. N.V. Kuzmina, Z.F. Esarova, M.G. Davletshin, M. Abdullajonova, T. Hamrokulov and others distinguish the following professional skills in the creation of a specialized profile - a professional profile of a secondary school teacher.

\section{Gnostic skills.}

\section{Constructive skills.}

\section{Communicativeness.}

\section{Organizational skills.}

Gnostic (Greek "gnosis" - "knowledge") skills related to the field of knowledge of the educator, the ability to determine the level of individual-psychological development of children; reflexive approach to their experience and pedagogical activity; learning best practices, innovation; be able to use pedagogical and psychological literature; embody skills in the field of empathy and pedagogical intelligence. Constructiveness (design ability) is the ability of the educator to design and organize the pedagogical process in a methodologically correct way. At the same time, forecasting the results of the educational process, purposeful design of the educational process, the correct definition of educational, pedagogical and developmental goals based on the age and individual characteristics of students and a clear definition of the technological structure of the course. related skills are implied. Communicativeness is a special feature of the educator, which involves interaction with students and colleagues. These include the ability of the educator to attract children, to organize, manage and control communication with students and parents, to communicate with them pedagogically and psychologically, to intensify interpersonal relationships. The success of pedagogical training in communication with students depends in many ways on the teacher's continuous acquisition of communicative skills and abilities, his ability to apply them. The organization is characterized by the educator's ability to organize a team of students, to unite the team, to activate the cognitive activity of students, to apply personal experience and advanced pedagogical ideas in the teaching process. It should be noted that these skills, which should be reflected in the professional image of the educator, are important not only in the interaction with students but also in relationships with others.

\section{CONCLUSION}

The concept of a systematic approach is noted differently by researchers. Some scientific papers are often limited to the category of integrity, in which a holistic description of the studied feature, event, and process is created. It can be concluded that the concept of "systematicity" can reflect the fact that processes and phenomena in existence can 
form a system, the existence of the system, the systemic construction of the material world and its forms of knowledge. So, in conclusion, the individuality, professional qualities, knowledge, skills and competencies of the individual are one of the important factors in the creative attitude of future teachers in the profession.

\section{REFERENCES}

1. National training program. Book: Harmoniously developed generation is the foundation of Uzbekistan's development. Tashkent: Sharq, 1997. 32-61 p.

2. Avliyoqulov N.H. (2001). Practical bases of a modular system of teaching and pedagogical technology. Methodical manual. Buxoro. P. 49

3. Askarov I. B. (2013). Application of modular teaching technology in teaching the subject "Maintenance and repair of cars and engines" in professional colleges. A dissertation written for a master's degree. Tashkent

4. Nishonova, D. J. (2017). Teorija i metodika obuchenija inostrannomu jazyku v vuze [Theory and methodology of teaching a foreign language at the university]. Nauchnye issledovanija, 1 (6 (17)). (in Russian).

5. Nishonova, D. Zh. (2019). Ispol'zovanie interaktivnyh metodov na urokah nemeckogo jazyka [Use of interactive methods on the lesson of the German language]. Voprosy nauki i obrazovanija, (4 (49)). (in Russian).

6. Jonibekovna, N. D., Gulomovna, B. G., Salimovna, T. O., \& Karimovna, M. O. (2020). Some opinions about parameters of mnemonics. Universal Journal of Educational Research, 8(1), 238-242.

7. Nishonova, D. J. (2018). Portfolio kak odin iz al'ternativnyh sposobov ocenivanija znanij uchashhihsja $v$ processe obuchenija inostrannym jazykam [Portfolio as one of the alternative ways of assessing students' knowledge in the process of teaching foreign languages]. In Nauka I Obrazovanie: Sohranjaja Proshloe, Sozdajom Budushhee (pp. 235-237). (in Russian).

8. Nishonova, D. J. (2018). Sredstva, modeli i prijomy pri obuchenii inostrannomu jazyku [Means, models and techniques for teaching a foreign language]. Dostizhenija nauki i obrazovanija, 1 (8 (30)). (in Russian).

9. Nishonova, D. J., Muminova, O. K., \& Ismoilova, F. A. (2019). Metod proektnyh rabot $\mathrm{v}$ obrazovatel'nom processe [Method proektnyx rabot in obrazovatelnom protsesse]. Vestnik nauki i obrazovanija, (19-2 (73)). (in Russian). 